\title{
Impact of decomposition of different manures on soil resistivity in rainy season
}

\section{GAURI U. PATIL}

Article Chronicle:

Received:

25.05.2017;

Accepted :

30.11.2017

Key Words :

Earthing installation, Electrical resistivity; Intrinsic property; manures, Deposition

\begin{abstract}
Knowledge of soil resistivity act as important parameter for designing earthing installations as well as fordeciding the type, coating of Underground pipes. Electrical resistivity is an intrinsic property that quantifies how strongly a given soil oppose the flow of electric current. In this paper we have focus to study the impact of decomposition of different manures like animal manures, plant manures on resistivity of soil in rainy season. We had assumed that there is negligible effect of change in temperature and moisture of soil on resistivity and resistivity decreases during decomposition of material. We have dig 7 different pits of same dimensions, inserted different manures in each pit,dipped electrodes at fixed distance and connected Multimeter to measured resistivity in botanical garden of C.K.Thakur A.C.S college, Panvel. It is witnessed that resistivity of soil increases initially for few days then decreases slowly also in rainy season. We also found that decomposition of cooked rice lowers the soil resistivity in rainy season also which is helpful to drain out leakage current through earthing process and direct us to use Plastic PVC Underground pipes in such soil.

HOW TO CITE THIS ARTICLE : Patil, Gauri U. (2017). Impact of decomposition of different manures on soil resistivity in rainy season. Asian J. Environ. Sci., 12(2): 138-143, DOI: 10.15740/HAS/AJES/12.2/138-143.
\end{abstract}

Author for correspondence : GAURI U. PATIL

Department of Physics, Changu Kana Thakur A.C.S. College, PANVEL (M.S.) INDIA

Email : thakurmadhuri vedant@rediffmail.com 